\title{
CHARACTERIZATION OF ROCK VARNISH FERROMANGANESE CRUSTS ON ANCIENT EGYPTIAN WALL PAINTINGS FROM BAHARIYA OASIS, EGYPT
}

\author{
Ahmed M. ELSHABRAWY ${ }^{1}$ and Mona A. FOUAD ${ }^{2}$ \\ Conservation department, Faculty of Archaeology, Cairo University, Egypt. \\ 1 E-mail: a7med.shabrawy@cu.edu.eg \\ 2 E-mail:monalyeg@yahoo.com
}

\begin{abstract}
The black crust phenomenon appears clearly in the Bannentiu tomb, an ancient Egyptian tomb back to the 26th dynasty in the Bahariya oasis, one of the main iron ores in Egypt's western desert. The black crusts are attributed to the high content of $\mathrm{Fe}$ and $\mathrm{Mn}$ oxides and oxyhydroxides components in the sandstone host rock formation as cement materials. Nondestructive investigations were carried out for the collected samples using optical microscopy, XRD, XRF, and SEM-EDX analyses. The observed results indicate that silica, iron, manganese compounds, clay minerals, and other remaining elements classify the black crusts as one of the rock varnish species. The present study aims to analyze and classify the chemical composition and mineralogy of the black crusts formed on the wall paintings of the Bannentiu tomb. Moreover, the study proposes a model formation for the rock varnish on the Bannentiu tomb wall painting. The proposed simulation relies on high ratios of $\mathrm{Fe}$ and $\mathrm{Mn}$ in the host rock and the microclimatic factors that cause the migration of these elements to the surface, with the oxidization factors giving rise to oxides and hydroxides low crystallinity.
\end{abstract}

\section{KEYWORDS}

Rock Varnish - Ferromanganese - Black crusts Iron oxides - wall paintings deterioration

\begin{abstract}
الملخص
تتضح ظاهرة القشرة السوداء في مقبرة بانينتيو ، وهي

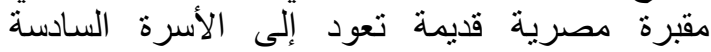
و العشرين في الواحات البحرية التي تعد أحد أهم خامات العات

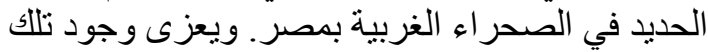

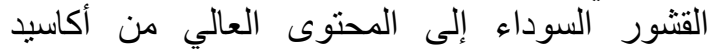

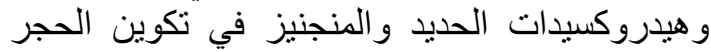

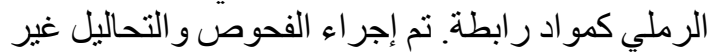

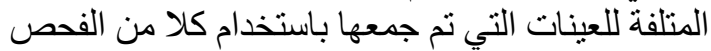

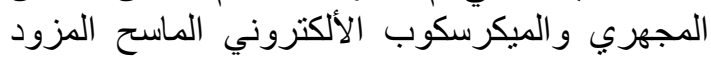

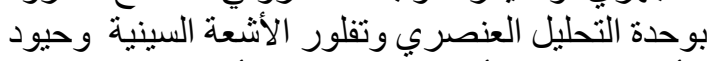

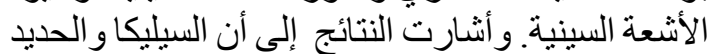

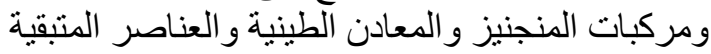

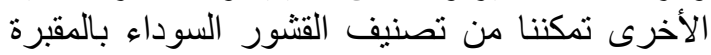
كأحد أنواع الورنبش الصنيا من الصني. تهدف الدراسة الحالية إلى تحليل وتصنيف التركيب

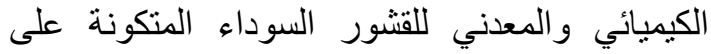

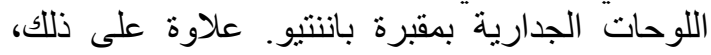
تقترح الدراسة نموذج محاكي للتكونها على الثى الاسطح

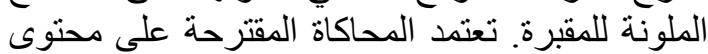

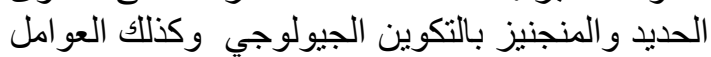

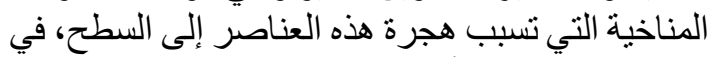

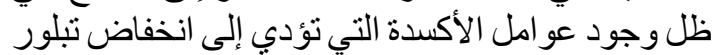
الأكاسيد و الهيدروكسيدات في طبقة الورنيش الصخري.
\end{abstract}

\section{الكلمات الدالة}

الورنيش الصخري - المنجنيز الحديدي - القنشور السوداء ـ أكاسيد الحديد ـ تدهور اللوحات الجدارية الجية 


\section{INTRODUCTION}

One of the challengeable problems of the archaeological wall paintings in Egypt is the black crusts that formed on the paintings' surfaces. According to the literature, black crusts appear in different shapes of regular and irregular layers depending on the host place's formation and microclimatic environmental factors. The danger of the black crusts phenomenon resides in distorting the beauty of historical paintings and striking valuable places of economic importance, such as the Bannentiu tomb. Bahariya oasis, considered one of the main iron ores in the heart of the western desert of Egypt ${ }^{1}$, Bannentiu's tomb dated to the $26^{\text {th }}$ dynasty (late period) of ancient Egyptian history ${ }^{2}$

Fakhry ${ }^{3}$ firstly reported black crusts of Bannentiu in 1937 A.B. Fakhry noticed that a rapidly formed crust appeared on the surface a year after discovering the tomb without any notes about the formation mechanism or the components of this layer. In 1993, $\mathrm{Ali}^{4}$ found that magnetite $\left(\mathrm{Fe}_{3} \mathrm{O}_{4}\right)$ exists in the black crust formation and attributed this to the mineral migration. Another study ${ }^{5}$ classified the black crusts into light and dark brown facies consisting of $\mathrm{Fe}, \mathrm{Mn}, \mathrm{Al}, \mathrm{Ca}, \mathrm{K}$, and $\mathrm{S}$ minerals. As previously mentioned, black crusts can be formed in different phases and shapes depending on the ambient conditions and their formation mechanisms. From the geological point of view, rock varnish is considered one of the black crusts faces. Rock varnish is described as dark coatings ${ }^{6}$ of microscale thicknesses ${ }^{7}$ that take hundreds of years or just a few years to form the stone's surfaces ${ }^{8}$. The rock varnish coatings are forming in different environments and surfaces (nodules, pebbles, boulders, rocks, stones, bedrocks, cliffs, caves, springs, fractures, soils, ocean ${ }^{9}$ and may exist on Mars ${ }^{10}$ ), and have several formation mechanisms such as geochemically, biologically, physically, or a combination of these mechanisms. The geochemical weathering occurs due to the migration of the inorganic constituents from the inner part of a rock to the surface, depending on the moisture content and gravity effect ${ }^{11}$. The biological formation takes place on the surfaces when the iron and manganese content oxidizes by microorganisms ${ }^{12}$. In the physical formation, the organic and inorganic components of the atmospheric dust precipitate on the outer surface ${ }^{13}$.

Clay minerals, silica, oxides, and oxyhydroxides of iron and manganese are the main components of the rock varnish layers and other trace elements such as magnesium, calcium,

\footnotetext{
${ }^{1}$ Baioumy\& Khedr\& Ahmed, Mineralogy, Geochemistry and Origin of $\mathrm{Mn}$ in the High-Mn Iron Ores, Bahariya Oasis, Egypt, 64.

${ }^{2}$ Sherbiny \& Bassir, The Representation of the Hedgehog Goddess Abaset at Bahariya Oasis, 173.

${ }^{3}$ Fakhry, The Oases of Egypt, II. Bahriyah and Farafra Oases, 128.

${ }^{4} \mathrm{Ali}$, Restoration study of wall paintingsin tombs dated to late period (twenty-sixth dynasty) with application on a selected tomb. (unPublished thesis), 185.

${ }^{5}$ Kamh et al., Geological and Geotechnical Parameters Controlling Wall Paints Detachment at Selected XXVI Dynasty Tombs, Bahariya Oasis, Egypt, 12.

6 Dorn \& Krinsley, Spatial, Temporal and Geographic Considerations of the Problem of Rock Varnish Diagenesis,92.; Dorn, “Desert Rock Coatings.”, 82.

7 Perry \& Kolb, Biological and Organic Constiuents of Desert Varnish", 203.; Vicenzi et al., "Rock Varnish on Architectural Stone, 26.

8 Dorn, Desert Rock Coatings, 113.

${ }^{9}$ Dorn, 4.5 Rock Coatings, 78.

${ }^{10}$ Marszałek\& Alexandrowicz\& Rzepa, Composition of Weathering Crusts on Sandstones from Natural Outcrops and Architectonic Elements in an Urban Environment, 4026.

${ }^{11}$ Dietzel et al., Desert Varnish and Petroglyphs on Sandstone - Geochemical Composition and Climate Changes from Pleistocene to Holocene (Libya), 41.

12 Perry et al., Amino Acid Analyses of Desert Varnish from the Sonoran and Mojave Deserts, 39.

${ }^{13}$ Nowinski, Desert Varnish as an Indicator of Modern-Day Air Pollution in Southern Nevada, 21.
} 
carbon, sodium, potassium, cobalt, phosphate, copper, and lead ${ }^{1}$. The apparent coating color varies depending on the ratio between the main constituent components; the high concentration of iron oxides besides clay minerals and silica causes red, orange, and brown coloration. At the same time, the high concentration of manganese oxides results in the black coloration of the coating ${ }^{2}$. The importance of the rock varnish layer came from the ability to use it as an indicator for climate change, millennial-scale, paleo-reconstruction, air pollution ratio, energy production from microorganisms' communities, and rock weathering phenomenon ${ }^{3}$ moreover, the presence of archaeological petroglyphs which engraved by scratching the rock varnish layer on stones ${ }^{4}$.

The present study aims to analyze the chemistry and mineralogy of the black crusts on the wall paintings of the Bannentiu tomb and their relationship with Bahariya sandstone deposits. However, Kamh et al. ${ }^{5}$ performed a study on some of these crusts in 2013 . To our knowledge, no literature to analyze neither the crust types nor the mineralogical construction in the archaeological sites was reported. Hence, the present study is a pioneer in analyzing the rock varnish on ancient Egyptian wall paintings containing iron pigments. Moreover, a simulation model for rock the varnish formation on the colored surfaces of the Bannentiu tomb, which is different from other reported cases of rock varnish formations, is proposed in this study.

\section{GEOLOGICAL STUDY OF BAHARIYA OASES:}

The Bahariya Depression is in the Western Desert of Egypt, about $365 \mathrm{~km}$ southwest of Giza Governorate, covering an area oval-shaped with the length $94 \mathrm{~km}$ and width $42 \mathrm{~km}$, and the total area about $1800 \mathrm{~km}^{2}$. The oasis is located between latitudes $27^{\circ} 48^{\prime}$ and $28^{\circ} 31^{\prime} \mathrm{N}$ and longitudes $28^{\circ} 30^{\prime}$ and $29^{\circ} 15^{\prime} \mathrm{E}^{6}$. The Bahariya Depression is formed by a dense outcrop succession of Upper Cretaceous -Lower Cenozoic sedimentary deposits, locally covered by Miocene volcanic rock ${ }^{7}$. The outcrops of the region include, from bottom to top, the Lower Cenomanian (Bahariya F.), the Upper Cenomanian (El Heiz F.), the Campanian (El Hefhuf F.), and the Maastrichtian (Khoman Chalk F.) ${ }^{8}$. These are unconformably overlain by the formations Eocene Naqb, Qazzun, and El Hamra. The Cretaceous-Eocene succession is unconformably overlain by the Oligocene Radwan Formation. The geological map and

\footnotetext{
${ }^{1}$ Wayne et al., Direct Major- and Trace-Element Analyses of Rock Varnish by High Resolution Laser Ablation Inductively-Coupled Plasma Mass Spectrometry (LA-ICPMS), 1411; Lozano and Rossi, "Exceptional Preservation of Mn-Oxidizing Microbes in Cave Stromatolites (El Soplao, Spain), 43.

2 Dietzel et al., Desert Varnish and Petroglyphs on Sandstone - Geochemical Composition and Climate Changes from Pleistocene to Holocene (Libya), 39; Esposito et al., Comparison of Rock Varnish Bacterial Communities with Surrounding Non-Varnished Rock Surfaces, 50; Frierdich, Hasenmueller, and Catalano, Composition and Structure of Nanocrystalline Fe and Mn Oxide Cave Deposits, 92; Perry and Kolb, Biological and Organic Constiuents of Desert Varnish, 215.

${ }^{3}$ Nowinski, Desert Varnish as an Indicator of Modern-Day Air Pollution in Southern Nevada, 14.

${ }^{4}$ Andreae et al., Geochemical Studies on Rock Varnish and Petroglyphs in the Owens and Rose Valleys, California, 2; Dietzel et al., Desert Varnish and Petroglyphs on Sandstone - Geochemical Composition and Climate Changes from Pleistocene to Holocene (Libya), 32.

${ }^{5}$ Kamh et al., Geological and Geotechnical Parameters Controlling Wall Paints Detachment at Selected XXVI Dynasty Tombs, Bahariya Oasis, Egypt, 28.

${ }^{6}$ Baioumy, Khedr, and Ahmed, Mineralogy, Geochemistry and Origin of $\mathrm{Mn}$ in the High-Mn Iron Ores, Bahariya Oasis, Egypt, 65.; Afify et al., Diagenetic Origin of Ironstone Crusts in the Lower Cenomanian Bahariya Formation, Bahariya Depression, Western Desert, Egypt, 49.

${ }^{7}$ Plyusnina, Sallam, and Ruban, Geological Heritage of the Bahariya and Farafra Oases, the Central Western Desert, Egypt, 59.

${ }^{8}$ Afify\& Sanz-Montero\& Calvo, Ironstone Deposits Hosted in Eocene Carbonates from Bahariya (Egypt)New Perspective on Cherty Ironstone Occurrences, 82.
}

Characterization of Rock Varnish Ferromanganese Crusts on Ancient Egyptian Wall Paintings from Bahariya Oasis, Egypt 
stratigraphic section of the Bahariya Oasis are described in (Fig.1) ${ }^{1}$. Bahariya formation, where the tomb was carved, is a rock unit consisting of clastic sedimentary deposits (sandstones, siltstones, clay stones, and shales) with subordinate carbonates, mainly representative of fluvio-marine facies. Ironstone crusts and concrete are abundant in lower and upper units ${ }^{2}$.
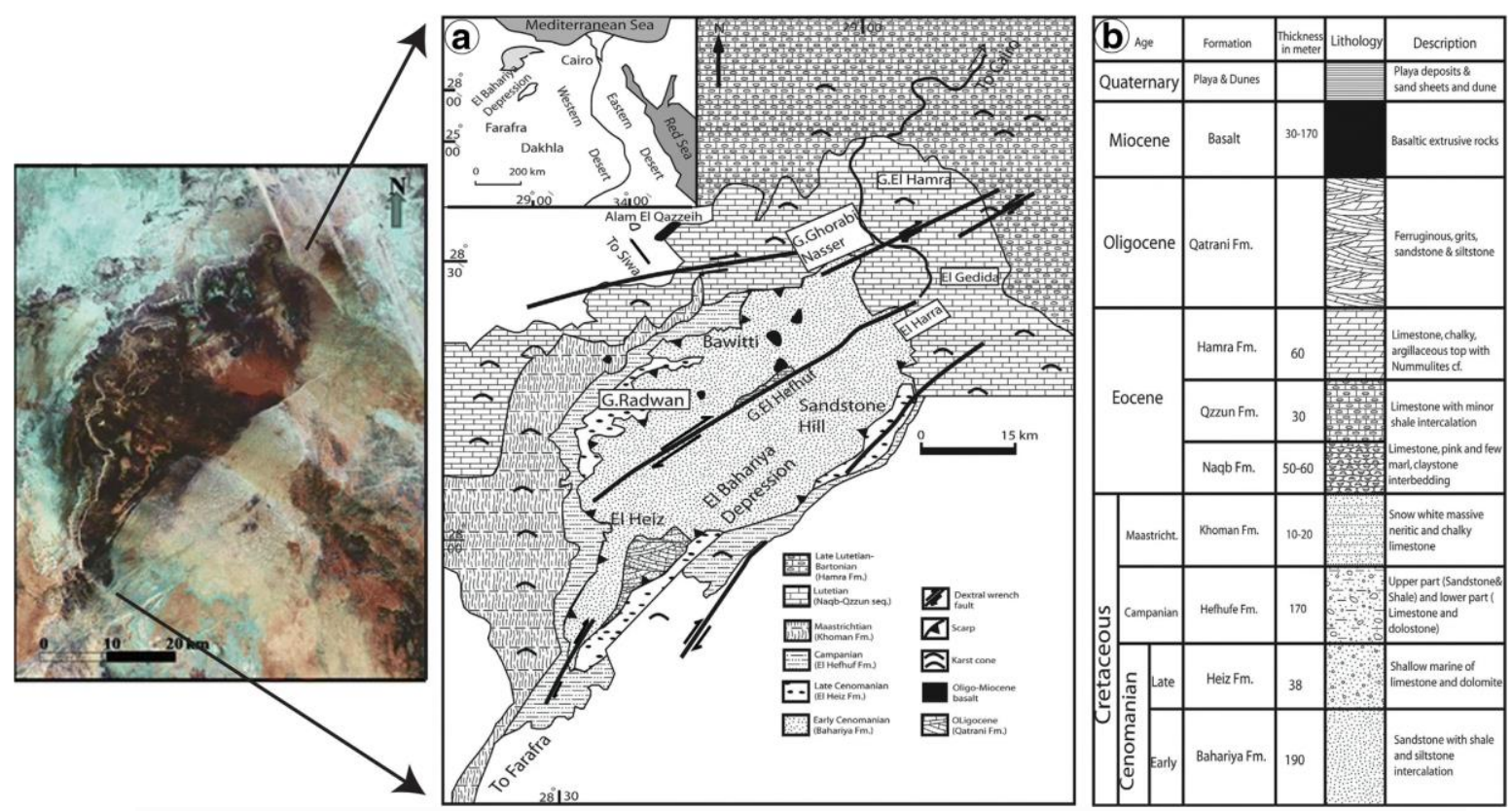

Fig.1 The geological map and stratigraphic section of the Bahariya Oasis, Western Desert, Egypt ${ }^{3}$.

\section{MATERIALS AND METHODS:}

\subsection{Samples collection}

Samples were collected from the falling deteriorated parts of wall paintings in the Bannentiu tomb without any damage or scratching; the collected samples represent the mural layers, including mixed plaster, gypsum whitewash, red and yellow pigments, and finally, the black crust layer. The represent pigments in samples are red and yellow colors, which indicate hematite and yellow ocher pigments.

\subsection{In-situ Investigations}

Wall paintings of the Bannentiu tomb were observed to determine the deterioration phenomena and quantify the main deterioration factors that affected the tomb. A portable USB digital light microscope (STPCTOU MX200-B - 1000X -2 Megapixel -1080 P HD) is used to investigate the morphology of black crusts and pigments. Temperature and relative humidity were measured from January 2019 to December 2019 inside and outside the tomb using a digital hygrometer (UniT UT332). The hydrogen potential $(\mathrm{pH})$ was measured for

\footnotetext{
${ }^{1}$ Khalifa et al., Volcanic Geosites and Their Geoheritage Values Preserved in Monogenetic Neogene Volcanic Field, Bahariya Depression, Western Desert, Egypt, 857.

${ }^{2}$ Afify\& Sanz-Montero\& Calvo, 49; Kamh et al., Geological and Geotechnical Parameters Controlling Wall Paints Detachment at Selected XXVI Dynasty Tombs, Bahariya Oasis, Egypt, 24; Catuneanu, Khalifa, and Wanas, Sequence Stratigraphy of the Lower Cenomanian Bahariya Formation, Bahariya Oasis, Western Desert, Egypt, 38; Plyusnina, Sallam, and Ruban, Geological Heritage of the Bahariya and Farafra Oases, the Central Western Desert, Egypt,62; Khalaf and Catuneanu, Sedimentology of the Fluvial and Fluvio-Marine Facies of the Bahariya Formation (Early Cenomanian), Bahariya Oasis, Western Desert, Egypt, 99.

${ }^{3}$ Khalaf et al., Volcanic Geosites and Their Geoheritage Values Preserved in Monogenetic Neogene Volcanic Field, Bahariya Depression, Western Desert, Egypt, 92.
} 
six samples from different areas and highs of painted surfaces on the tomb walls using the Adwa AD 8000 Bench meter.

\subsection{Laboratory Investigations}

Non-destructive examination and analysis methods were carried out to characterize the components of wall paintings and black crust layer; depending on the importance of these samples; the investigations were carried in order.

3.3.1. Polarized Light Microscopy, a thin section petrography sample, was prepared for class structure examination and mineral-containing materials using the PLM (Olympus BX40- Faculty of Science- Cairo University).

3.3.2. Scanning Electron Microscopy with an Energy Dispersive X-Ray analysis SEM-EDX (Quanta FEG 250- National research center of Egypt) has been used to examine the morphology of the crust surface under $20.00 \mathrm{kV}$, and two spot areas of EDX used to identify elements of the black crust in every sample.

3.3.3. X-Ray Fluorescence Spectrometry (Axios advanced, Sequential WD_XRF Spectrometer, PANalytical 2005 - National research center of Egypt) has been used to determine the elements in two brown samples black crusts with wall painting layers.

3.3.4. X-Ray Powder Diffraction (Burker D8 Discover - Faculty of NanoscienceCairo University) has been used to identify the crystallized minerals inside twocrust and painting layers samples, using $\mathrm{Cu}-\mathrm{K} \alpha$ radiation $1.54053 \AA$ at the power of $40 \mathrm{kV}$. Data were collected over a range of $5-80^{\circ} 2 \theta$ using a $0.02^{\circ}$ step size and a 4 second. Results were analyzed by (Qualx software with pow-cod2008 database).

\subsection{Simulation model of the Rock Varnish Formation}

A theoretical simulation illustrated with infographics of rock varnish formation mechanism in Bannentiu was proposed according to the results obtained from the current study. The simulation was divided into three sequential processes. Firstly, chemical elements dissolute inside the host rock due to the alkaline moisture content in extended periods during tomb closure. Secondly, the movement of chemical elements and compounds across the layers due to the capillary property in the sandstone and mural layers pores to the outer surfaces due to airflow and the change in humidity levels and atmospheric pressure inside the tomb after excavation. Finally, the oxidation and reduction processes of migrated ions on the outer surface of the wall paintings cooperated with the pigment materials and forming the final crust layers.

\section{RESULTS AND DISCUSSION:}

\subsection{In-situ investigations:}

The field study showed that the wall paintings inside the tomb were painted with tempera technique with two plaster layers and whitewash from gypsum covered with ancient Egyptian paintings containing pigments and organic media. Many colorful bedding layers can be shown from the tomb's unfinished rooms, which contain manganese-rich, iron-rich, clay minerals layers banded the quartz grains in the sandstone support and with many cracks and faults (Fig.1-B). The wall painting in the tomb has many deterioration phenomena spread in the tomb walls mainly crumbling, abrasion, peeling, flaking, Bulge, pigment alteration, dusty films, black crusts in the middle of walls and brown crusts in the upper parts of the walls, and finally, the missing lower part of all painted walls appears as a tape of $\approx 40 \mathrm{~cm}$ high (Fig.1-A).

The pronounced data that recorded the difference between the temperature and relative humidity (R.H.) degrees inside and outside the tomb are represented in (Table 1). The results 
in standard cases indicate the higher rates of R.H. inside the tomb than outside because the tomb is a closed space carved inside a sandstone plateau. It contains no ventilation sources except the tom exit $(1 * 1 \mathrm{~m})$ opening to the bottom of a vertical well that leads to the outside (6 m high). Accordingly, it is not well ventilated; thus, the airflow is slow, and the temperatures are almost constant. Consequently, the humidity increases and the atmospheric pressure increases with it, especially in summer. Inside the tomb, there was a work dehumidifier instrument (Aerial dehumidifier - AD series 550 "old version"). These measurements indicate the inefficiency of the device used in fulfilling its purpose, Where the region's specialists set up the machine at $45 \%$ R.H. Despite that, the R.H. was high, except in the winter season when the R.H. levels naturally dropped, which was close to the device setting rate.

\section{Table 1.}

Temperature and Relative humidity Climate data collected over four seasons inside and outside the tomb

\begin{tabular}{llllccccc}
\hline & Winter & \multicolumn{2}{c}{ Spring } & \multicolumn{2}{c}{ Summer } & \multicolumn{2}{c}{ Autumn } \\
\hline Average & Temp. C & R.H. \% & Temp. C & R.H. \% & Temp. C & R.H. \% & Temp. C R.H. \% \\
\hline Inside Tomb & 22 & 49 & 25 & 62 & 27 & 70 & 24 & 53 \\
\hline Outside Tomb & 20 & 68 & 34 & 56 & 42 & 48 & 32 & 46 \\
\hline
\end{tabular}

USB-Digital Microscope was used to determine the black crusts' optical properties; these crusts appeared glossy, interrupted smoothly from the upper surface, granular in the inner surface, and superfine layer. The examination also showed that the spread of black crusts is more widely and dark in red-hematite and yellow ocher painted areas than in other areas with irregular distribution in all pigment materials (Fig.2-A). Morphology of black crusts nested with pigments and whitewash can be shown smooth and not always straight with thin thickness. Black crusts are homogeneously distributed and are more coherent with yellow and red pigments (Fig.2-D, E) than extinct blue pigments (Fig.2-F). Salt crusts existing on the lower parts of the wall paintings, black particles migrated from inner support appeared inside salt crusts (Fig.2-H). black crusts of rock varnish have the same color and texture properties as its appearance in caves and arid desert with a smooth and lustrous texture vary in color between brown and black.

The potential of hydrogen $(\mathrm{pH})$ was measured for six samples, and the results showed a ranged value of $\mathrm{pH}$ between (6.2 9.8). The differences of $\mathrm{pH}$ degrees back to samples place the high degrees samples taken from detached parts from low parts of the wall nearing to the tomb floor and in the middle parts of walls where the black crusts existed the $\mathrm{pH}$ value varying between $6.2 \sim 8.6$ in crusts. 

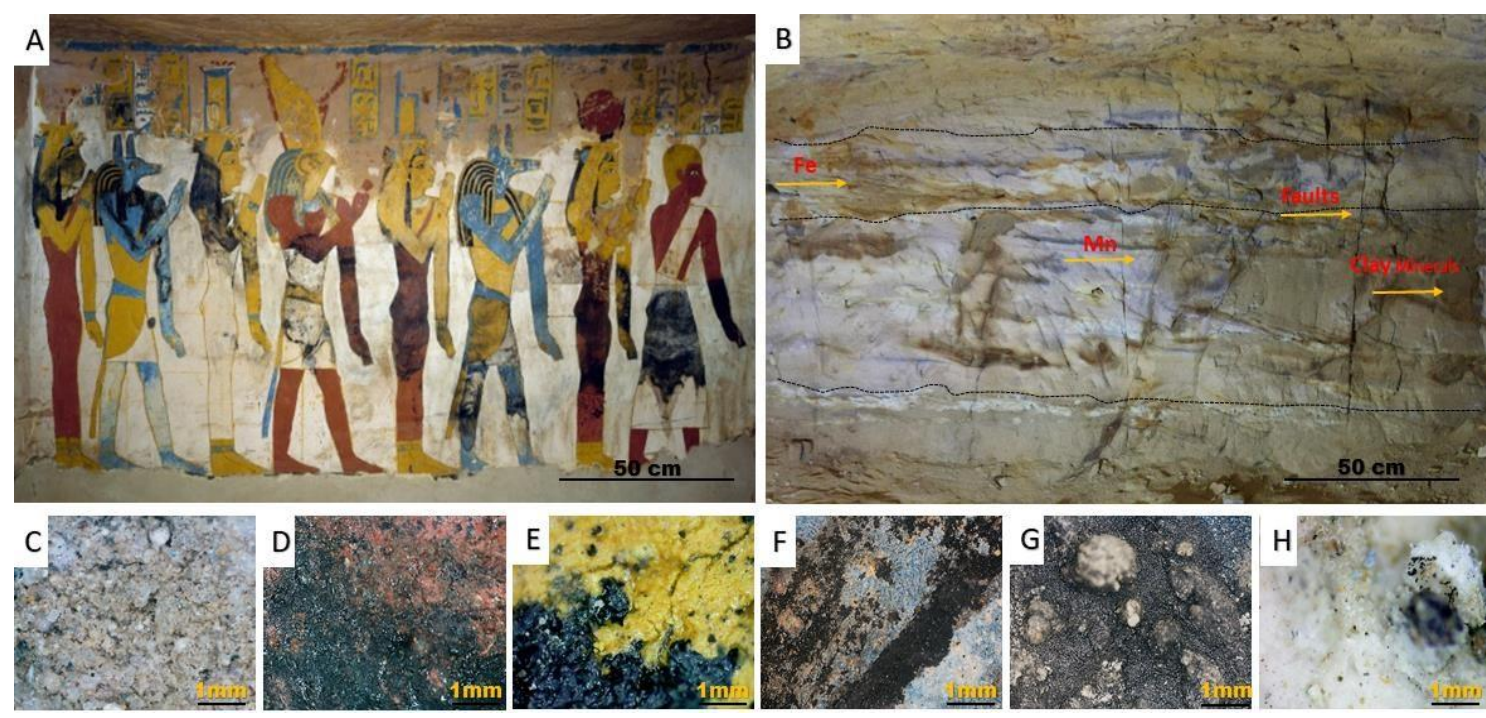

Fig.2. A) wall painting from Bannentiu tomb black and brown crusts can be showed with irregular distribution in all color materials. B) Iron and Manganese rich-sandstone support in unfinished rooms in the tomb. C) microscopic photograph for the whitewash layer shows the dust and small amounts of

black particles. Both D, E, F) show that black crusts' morphology exists on red, yellow, and blue pigments. G) Morphology of dirt and black particles on the surface of white figures in the painting. H) Migrated salts with black and blue particles inside white areas in paintings.

\subsection{LABORATORY INVESTIGATIONS:}

\subsubsection{PLM}

Under the polarizing microscopy, a varied thickness layer is seen in the upper part of the sample with a yellowish-brown fine layer in direct polarized light (Fig.3 -A). which consists of two different types (laminated layer followed by rubbly layer) with ferruginous compounds penetrate inside the yellow ocher pigment layer (Fig.3 -B), followed by thick multilayered plaster, which mainly contains gypsum, quartz, and calcite. The first evidence in rock varnish that appeared in the cross-section sample is the existence of the laminated and rubbly layers; these layers appeared in a varied thickness of $5-100 \mu \mathrm{m}$ covered with a dusty layer. A second feature evident in varnish is cracks, divided according to their alignment with the varnish surface into horizontal and vertical cracks ${ }^{1}$. Cut through the laminations and do not fully trace the laminations. Thus, these cracks are probably a local post-depositional phenomenon formed during the varnish accumulation; the low concentration of Mn content in the sample does not allow separation between laminas, the same case in samples of the Negev desert ${ }^{2}$.

\footnotetext{
${ }^{1}$ Dorn\& Krinsley, Spatial, Temporal and Geographic Considerations of the Problem of Rock Varnish Diagenesis, 92.

${ }^{2}$ Goldsmith, Characterizing Rock Varnish Developed on Earliest Holocene Negev Flint Artifacts as a Potential Paleoenvironmental or Paleoclimatic Indicator, 18.
} 

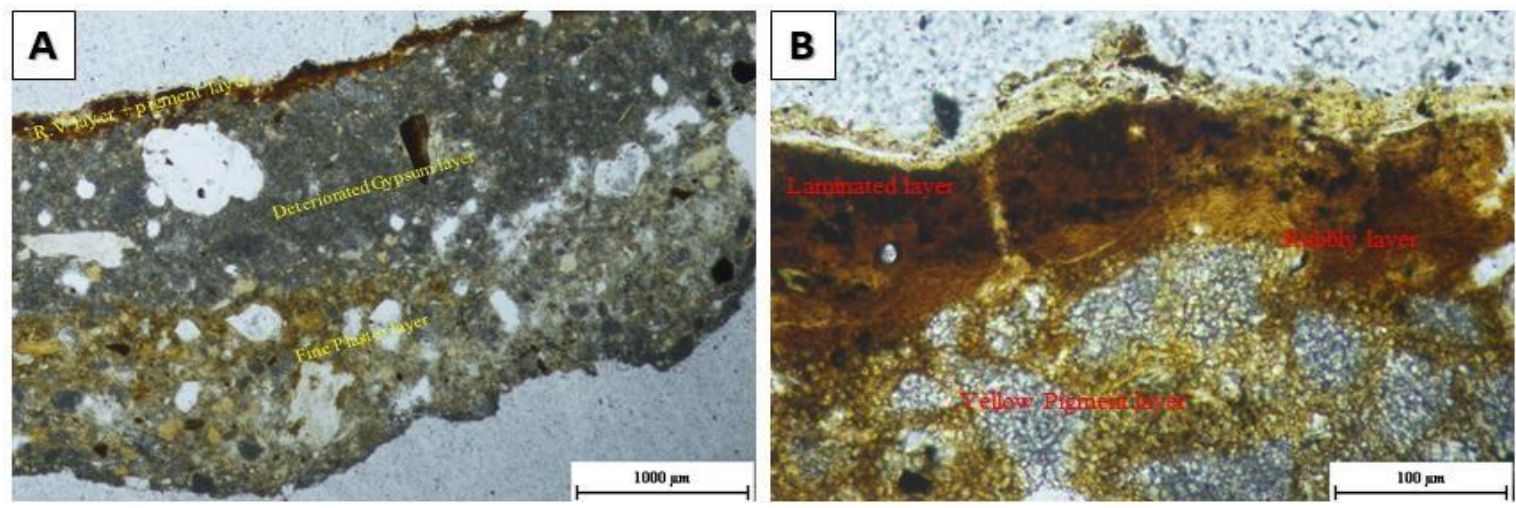

Fig.3. Thin section of rock varnish layer with the yellow pigment layer and plaster layer. A) the stratification of layers from above rock varnish, yellow pigment with silica particles, gypsum, and plaster layer from sand and calcite with iron oxides. B) rock varnish Laminated and Rubbly layers in the upper layer followed by mixed quartz and yellow pigment.

\subsubsection{SEM-EDX}

SEM also confirms a considerable similarity of rock varnish on the surface of wall paintings. Most of the rock varnish layer optical properties mentioned above are commensurate with SEM results; in addition to that, the upper layer shows a smooth and glossy appearance and includes some compounds from the plaster and paint layer (Fig4-A). The EDX also identified $(\mathrm{O}, \mathrm{C}, \mathrm{Na}, \mathrm{Si}, \mathrm{Cl}, \mathrm{K}, \mathrm{Ca}, \mathrm{Cr}, \mathrm{Mg}, \mathrm{Mn}, \mathrm{Fe}, \mathrm{Al}$ ) the scanned areas as to the analysis point for each sample scan. Trace elements appeared in results with a different amount such as $(\mathrm{Mg}$, $\mathrm{Cr}$, and $\mathrm{K}$ ), and the mainly exist minerals indicates mainly oxides and hydroxides of iron and manganese compounds mixed with other compounds of calcite, silica, clay minerals, halite, and k-feldspar with the varied amount each sample (Table 2). The outer layer can be identified as multiple components with very fine and smooth parts and interspersed with many particles of gypsum, halite, kaolinite, and iron oxides from external shapes (Fig.4- B). Gypsum, Calcium carbonate, iron oxides, K-feldspar, kaolinite, and quartz particles can be identified in spaces between the smooth crust surfaces (Fig.4-C). It also elucidates loss of cohesion with deformation over binding materials and quartz with flaks of k-feldspar and other clay minerals adjacent with very small conglomerates of manganese and iron compounds (Fig.4-D). 

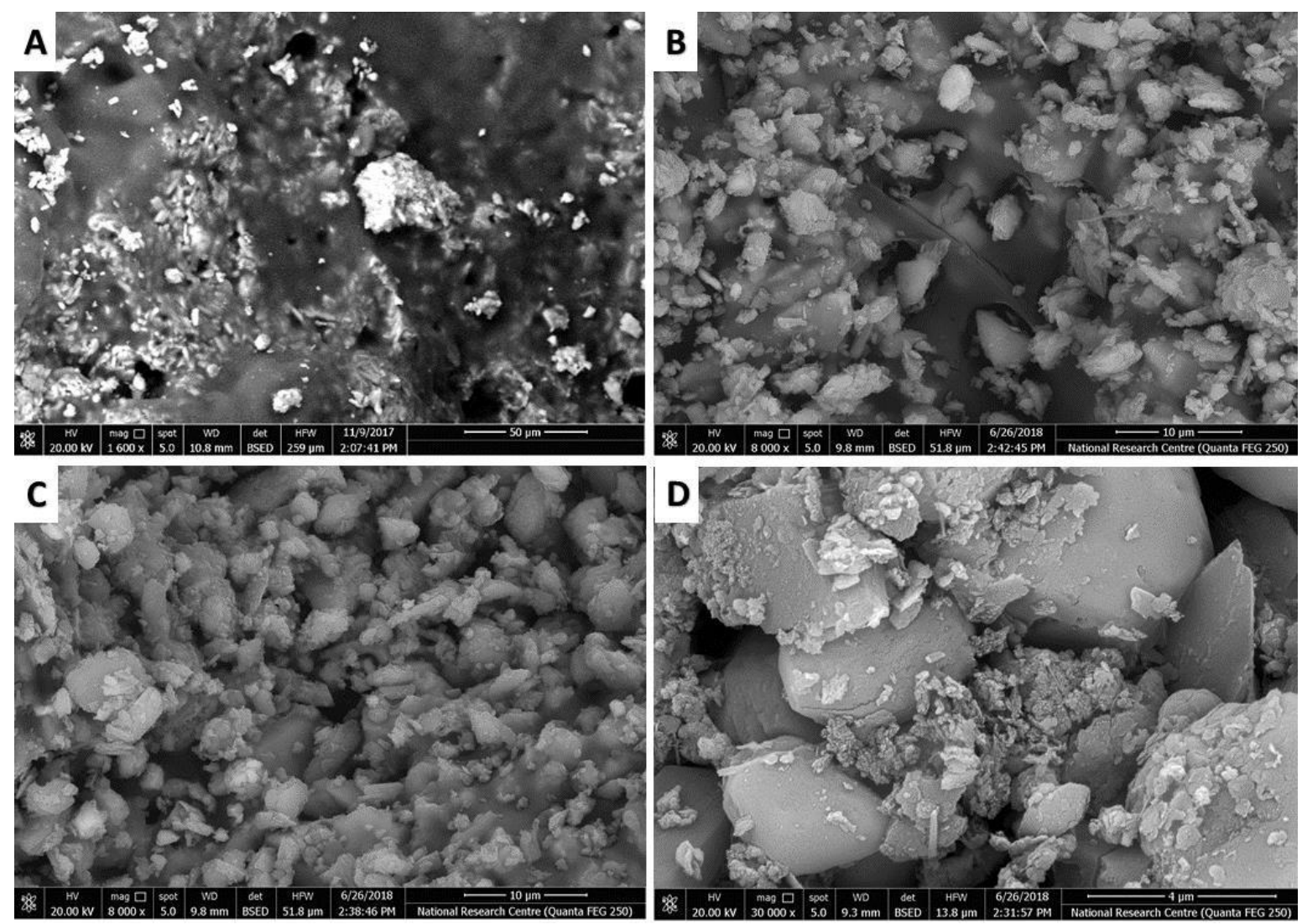

Fig.4. SEM images of the upper surface of the rock varnish layer exist on yellow pigment, conglomerates of manganese appeared with impurities from quartz, calcite, and gypsum from wall paintings, plaster and clay minerals, and iron oxides as immigrant particles from sandstone support and plaster layers. A) smooth rock varnish layer exists on yellow ocher pigment. B) integrated components between the smooth layer of rock varnish with micro-cracks inside the varnish layer. $\mathrm{C}$ ) calcite, gypsum, iron, manganese, and clay minerals particles in rough areas of rock varnish. D) Quartz grains with clay and $k$-feldspar minerals flaks and amounts of Fe and Mn oxides.

Table 2. EDx data results for elemental analysis of rock varnish layer

\begin{tabular}{|c|c|c|c|c|c|c|c|c|c|c|c|c|c|c|}
\hline & $\underset{(w t \%)}{\mathbf{O}}$ & $\underset{(\mathrm{wt} \%)}{\mathbf{C}}$ & $\begin{array}{c}\mathbf{N a} \\
(\mathrm{wt} \%)\end{array}$ & $\begin{array}{c}\mathbf{S i} \\
(w t \%)\end{array}$ & $\begin{array}{c}\text { Mo } \\
\text { (wt } \%)\end{array}$ & $\underset{(w t \%)}{\mathbf{S}}$ & $\begin{array}{c}\mathbf{C l} \\
(w t \%)\end{array}$ & $\underset{(w t \%)}{\mathbf{K}}$ & $\begin{array}{c}\text { Ca } \\
(w t \%)\end{array}$ & $\begin{array}{c}\mathbf{C r} \\
(\mathrm{wt} \%)\end{array}$ & $\begin{array}{c}\mathbf{M g} \\
(\mathrm{wt} \%)\end{array}$ & $\begin{array}{c}\text { Mn } \\
(w t \%)\end{array}$ & $\begin{array}{c}\mathbf{F e} \\
(w t \%)\end{array}$ & $\begin{array}{c}\mathbf{A l} \\
(\mathrm{wt} \%)\end{array}$ \\
\hline \multirow[t]{2}{*}{ A } & 39.05 & 27.82 & 1.28 & 2.97 & 0.51 & 0.71 & 1.12 & 1.56 & 1.65 & - & - & 6.99 & 5.61 & 1.72 \\
\hline & 36.8 & 33.01 & - & 2.68 & - & 1.09 & - & 1.48 & 2.14 & - & - & 18.95 & 2.6 & 1.25 \\
\hline \multirow[t]{2}{*}{ B } & 37.31 & 36.85 & 0.03 & 1.02 & - & 0.69 & 0.01 & - & 2.59 & - & - & 18.93 & 1.54 & 1.03 \\
\hline & 41.5 & 31.41 & 1.17 & 3.29 & - & 2.79 & 1.33 & - & 8.25 & - & - & 5.44 & 2.65 & 0.59 \\
\hline \multirow[t]{2}{*}{ C } & 33.17 & 45.34 & & 2.87 & - & 3.05 & - & - & 6.11 & 0.66 & 0.35 & 5.13 & 2.39 & 1.02 \\
\hline & 36.85 & 51.45 & - & 2.78 & - & 1.61 & - & - & 4.83 & - & - & 1.78 & 0.32 & 0.38 \\
\hline \multirow[t]{2}{*}{ D } & 51.23 & 8.25 & 0.01 & 1.12 & - & 13.09 & 0.35 & - & 19.42 & - & 0.22 & 0.23 & - & 3.54 \\
\hline & 45.9 & 33.62 & 0.01 & 2.07 & - & 4.76 & 0.8 & - & 8.26 & - & - & 1.2 & 2.16 & 0.87 \\
\hline AVER & 40.22 & 33.46 & 0.31 & 2.35 & 0.06 & 0.45 & 3.47 & 0.38 & 6.65 & 0.08 & 0.07 & 7.33 & 2.15 & 1.25 \\
\hline St dev & 1 & 0.831 & 0.007 & 0.058 & 0.001 & 0.011 & 0.086 & 0.009 & 0.16 & 0.002 & 0.0017 & 0.18 & 0.053 & 0.031 \\
\hline
\end{tabular}

\subsection{XRF}

X-ray Fluorescence was used to analyze two samples from the Bannentiu tomb. Each sample represents one phase of rock varnish with Micro core size for varnish, pigment plaster, and sandstone support (B.L.: black phase - CL: clay phase). The results of Major elements ( $\mathrm{Si}$, $\mathrm{Ti}, \mathrm{Al}, \mathrm{Fe}, \mathrm{Mn}, \mathrm{Mg}, \mathrm{Ca}, \mathrm{Na}, \mathrm{K}, \mathrm{P}, \mathrm{S}$, and $\mathrm{Cl}$ ) were the same in the samples with different ratios, which indicates the existence of minerals and compounds migrated from sandstone and plaster layers to the surface in both of black and clay phase of samples with a small ratio 
of salts. The difference of trace elements between $\mathrm{BL}$ sample $(\mathrm{Ni}, \mathrm{Cu}, \mathrm{Pb}, \mathrm{Sr}, \mathrm{Zr}, \mathrm{As}$, and $\mathrm{Co})$ and sample $\mathrm{CL}(\mathrm{Cu}, \mathrm{Sr}, \mathrm{Zr}, \mathrm{Zn}, \mathrm{Rb}, \mathrm{Cr}$, and $\mathrm{Y})$ indicates to the migrated elements from the sandstone to the outer surface depending on the elements mass weight (Table 3 ).

Table 3. XRF data results for Elemental analysis of rock varnish layer

\begin{tabular}{|c|c|c|c|c|c|c|c|c|c|c|c|c|c|}
\hline \multicolumn{14}{|c|}{ Major Elements (wt \%) } \\
\hline & $\mathrm{SiO}_{2}$ & $\mathrm{TiO}_{2}$ & $\mathrm{Al}_{2} \mathrm{O}_{3}$ & $\mathrm{Fe}_{2} \mathrm{O}_{3}$ & MnO & MgO & $\mathrm{CaO}$ & $\mathrm{Na}_{2} \mathrm{O}$ & $\mathrm{K}_{2} \mathrm{O}$ & $\mathrm{P}_{2} \mathrm{O}_{5}$ & $\mathrm{SO}_{3}$ & Cl & LOI \\
\hline BL & 6.88 & 0.15 & 0.22 & 2.24 & 1.89 & 0.52 & 30.07 & 0.33 & 0.19 & 0.06 & 36.82 & 0.31 & 19.35 \\
\hline CL & 23.59 & 0.22 & 1.82 & 2.42 & 0.04 & 5.64 & 22.78 & 0.06 & 0.27 & 0.06 & 24.71 & 0.27 & 17.46 \\
\hline \multicolumn{14}{|c|}{ Trace Elements (wt \%) } \\
\hline & & $\mathrm{NiO}$ & $\mathrm{CuO}$ & PbO & SrO & $\mathrm{ZrO}_{2}$ & $\mathrm{As}_{2} \mathrm{O}_{3}$ & $\mathrm{Co}_{3} \mathrm{O}_{4}$ & $\mathrm{ZnO}$ & $\mathbf{R} \mathbf{b}_{2} \mathbf{O}$ & $\mathrm{Cr}_{2} \mathrm{O}_{3}$ & $\mathbf{Y}_{2} \mathbf{O}_{3}$ & \\
\hline BL & & 0.013 & 0.116 & 0.007 & 0.089 & 0.042 & 0.005 & 0.011 & $\mathrm{bdl}$ & $\mathrm{bdl}$ & $\mathrm{bdl}$ & bdl & \\
\hline $\mathbf{C L}$ & & bdl & 0.204 & bdl & 0.311 & 0.098 & bdl & bdl & 0.003 & 0.003 & 0.032 & 0.002 & \\
\hline
\end{tabular}

\subsubsection{XRD}

Mineralogical analysis of two samples (DR and DY) by XRD detected various mineral phases of iron and manganese oxides, clay minerals, quartz, and remains of mural layers. Most of these minerals are low crystallinity degrees. The first sample DR was a black crust collected from a mural with red ocher pigment and a micrometre thickness layer of whitewash, while the second sample DY was a black crust based on yellow ocher pigment and the same thickness of whitewash layer. Results of both samples showed in (Fig.5) are classified based on main layers: whitewash layer group (alite, gypsum, quartz, halite, and calcite), pigment layers (goethite and hematite-proto), and the crust layers (birnessite, periclase, serandite, manganosite, bixbyite, berlinite, manganite, and spinel). Halite is a common mineral found in wall paintings as a deterioration phenomenon. Its ions are transported from soil and rocks by moisture content to be crystallized on surfaces and internal pores. 

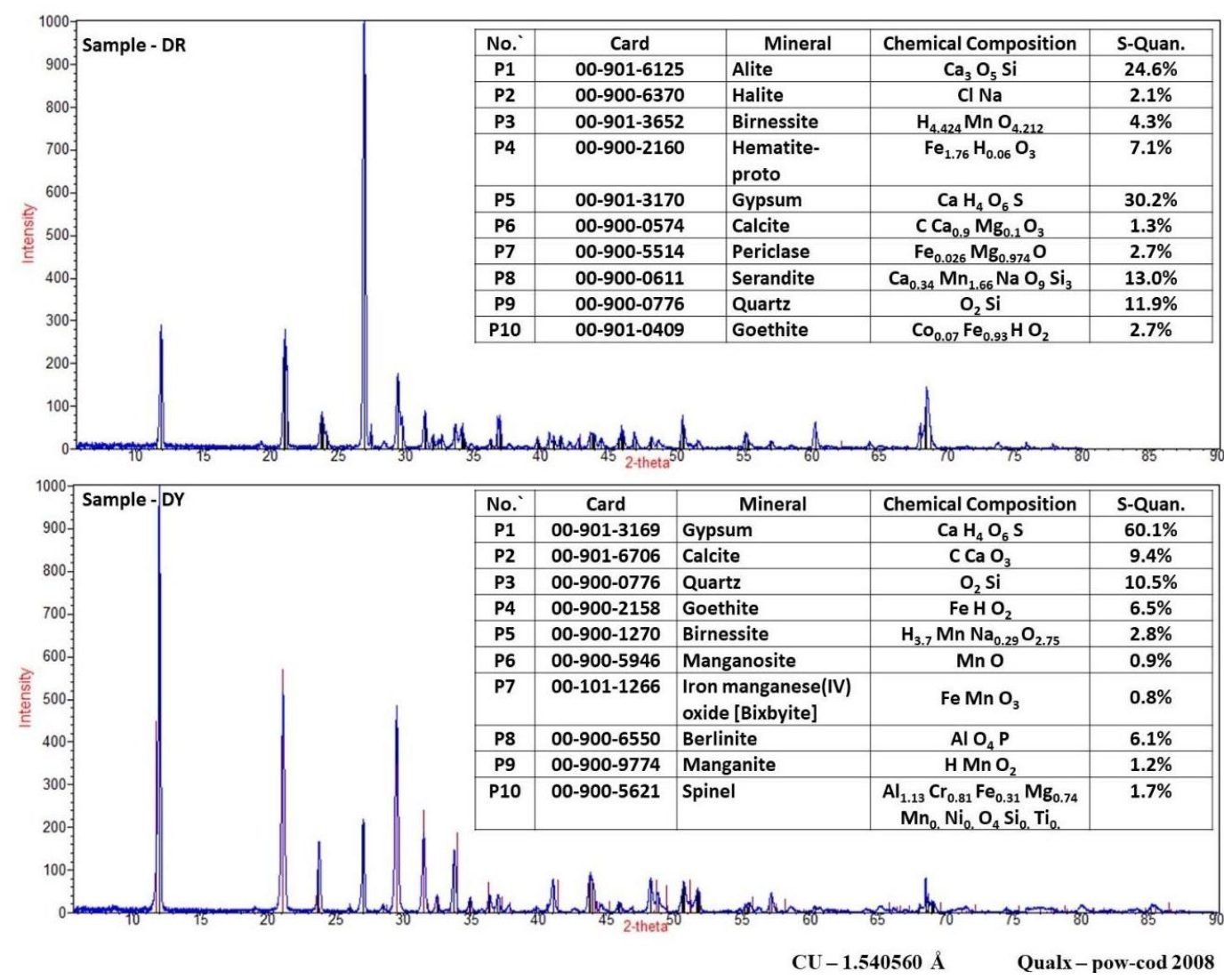

Fig.5. The samples' powder X-ray diffractograms. (DR) sample of rock varnish exists on red ocher pigment introduced alite, halite, birnessite, hematite-proto, gypsum, calcite, periclase, serandite, quartz, and goethite. (DY) sample of black rock varnish based on yellow ocher pigment results introduced multi-minerals: gypsum, calcite, quartz, goethite, birnessite, manganosite, bixbyite, berlinite, manganite, and spinel.

\subsection{MORPHOLOGICAL CHARACTERIZATION:}

Black crusts in the Bannentiu tomb show similar features of rock varnish, shiny black and red-brown colors, and superfine layers in the upper surface granular in the inner surfaces and overlaps with paint layers. Polarized light clarified the dark and light brown colors for the crust with the smooth covering of silicates. These properties matched with the characterization of rock vanish in natural caves, arid deserts. Despite the similarity in optical and morphological characteristics between rock varnish in most environments and black crusts in the Bannentiu tomb, the unique case of Bannentiu as a painted tomb makes a big difference in the type, composition appearance, and formation mechanism of these crusts. A scanning electron microscope showed that grains of mineral crystals, amorphous, and weakly crystallized minerals interconnected in one layer with a smooth glazed binding. However, quartz, K-feldspars, halite, iron oxides, and other grains from plaster layers appear randomly at large magnification. These deformations and randomness indicate mechanical stresses and components displacements due to migration from under layers by high moisture content and wet and dry cycles confirmed by salt weathering mechanisms described in the deterioration of wall paintings ${ }^{1}$.

\footnotetext{
${ }^{1}$ Rosina\& Sansonetti\& Erba, "Focus on Soluble Salts Transport Phenomena: The Study Cases of Leonardo Mural Paintings at Sala Delle Asse (Milan), 651.
}

Characterization of Rock Varnish Ferromanganese Crusts on Ancient Egyptian Wall
Paintings from Bahariya Oasis, Egypt 


\subsection{CHEMICAL COMPOSITION}

Bannentiu tomb is carved inside sandstone plateau and does not like arid desert rocks, petroglyphs, natural caves, oceans, soil, or even Mars. Five types of desert varnish are classified according to the formation mechanism and surrounding environment ${ }^{1}$; the most similar of these types are in terms of the chemical and physical properties of the rock varnish layer formed in Bannentiu are fourth and fifth types. As Macholdt ${ }^{2}$ mentioned, classification $4^{\text {th }}$ type mainly growth on urban building facades with a thickness rate from $\mu \mathrm{m}$ per a few decades, and significant chemical composition of Mn-rich in varnish matrix, Fe-rich in mineral grains, and $\mathrm{Pb}(0.2-1.4 \%)$. However, in the $5^{\text {th }}$ type, the varnish formed on river splash zones with a growth rate of $5 \mu \mathrm{m}$ per $10-100$ years, and it generally consists of asymmetric layers of iron, manganese, and calcium. So, the two types of varnish are similar to Bannentiu tomb varnish in main composition and growth rate but different information environment and formation mechanisms. Moisture in the Bannentiu tomb due to many resources' such as hygroscopic moisture through subsurface water, condensation, ironmanganese rich groundwater, and rainwater leaking through the cracks ${ }^{3}$. Sandstone support from Qasr Selim plateau follows Bahariya formation, rich in iron and manganese oxides and oxyhydroxides $^{4}$. Murals in the tomb contain multi-structure layers; primary layers consist of calcium carbonate and quartz followed by the gypsum layer, and finally, the painting layer contains iron oxides pigments, carbon pigment, and copper-based pigments banded with Arabic gum as a painting media.

From these results, the theoretical simulation of the rock varnish formation mechanism is unique from other models suggested in other reported cases ${ }^{5}$. In this proposed simulation, the multi-sources of moisture are responsible for water content flows in both directions, vertical and horizontal, and cause the total saturation of internal pores in sandstone. Water flow in pores causes the disintegration of minerals and other binding materials in sandstone bedrock ${ }^{6}$, ions from disintegrating minerals migrate with pellicular moisture flow towards the inner surfaces of the tomb as the nearest space inside the plateau. Before the tomb's excavation in 1937 AD, the relative humidity was very high but stable because the tomb was closed for thousands of years. So, the water in the pores did not move to the tomb surface, but with the opening of the tomb, the changing of airflow followed by changes in relative humidity caused the movement of ion-laden water through sandstone pores showed in (Fig.6). Ion-laden water follows the exact behavior of salt weathering, where the chlorine and sodium ions carried high moisture content inside stone pores to the outer surfaces. In drying and wetting cycles

\footnotetext{
${ }^{1}$ Macholdt et al., Characterization and Differentiation of Rock Varnish Types from Different Environments by Microanalytical Techniques, 116.; Dorn, Desert Rock Coatings, 159-160.

${ }^{2}$ Macholdt et al., Characterization and Differentiation of Rock Varnish Types from Different Environments by Microanalytical Techniques, 116-117.

${ }^{3}$ Kamh et al., Geological and Geotechnical Parameters Controlling Wall Paints Detachment at Selected XXVI Dynasty Tombs, Bahariya Oasis, Egypt, 28.; Baioumy\& Khedr \& Ahmed, Mineralogy, Geochemistry and Origin of Mn in the High-Mn Iron Ores, Bahariya Oasis, Egypt., 68.

${ }^{4}$ Afify et al., Diagenetic Origin of Ironstone Crusts in the Lower Cenomanian Bahariya Formation, Bahariya Depression, Western Desert, Egypt, 338.; Plyusnina, Sallam, and Ruban, "Geological Heritage of the Bahariya and Farafra Oases, the Central Western Desert, Egypt, 154.

${ }^{5}$ Chen et al., Visible-Light-Driven Photocatalysis of Carbon Dioxide and Organic Pollutants by MFeO2 $(\mathrm{M}=\mathrm{Li}, \mathrm{Na}$, or K), 761; Krinsley, Dorn, and DiGregorio, Astrobiological Implications of Rock Varnish in Tibet,560; Esposito et al., Comparison of Rock Varnish Bacterial Communities with Surrounding NonVarnished Rock Surfaces, 742; Krumbein and Jens, "Biogenic Rock Varnishes of the Negev Desert (Israel) an Ecological Study of Iron and Manganese Transformation by Cyanobacteria and Fungi, 36.

${ }^{6}$ Dietzel et al., Desert Varnish and Petroglyphs on Sandstone - Geochemical Composition and Climate Changes from Pleistocene to Holocene (Libya), 42.
} 
with natural air, moisture, and temperature on the surfaces, salt crystals take a position on the surface and between outer layers in pores as the mechanisms of salt weathering are described by Groot $^{1}$ and Rosina ${ }^{2}$.

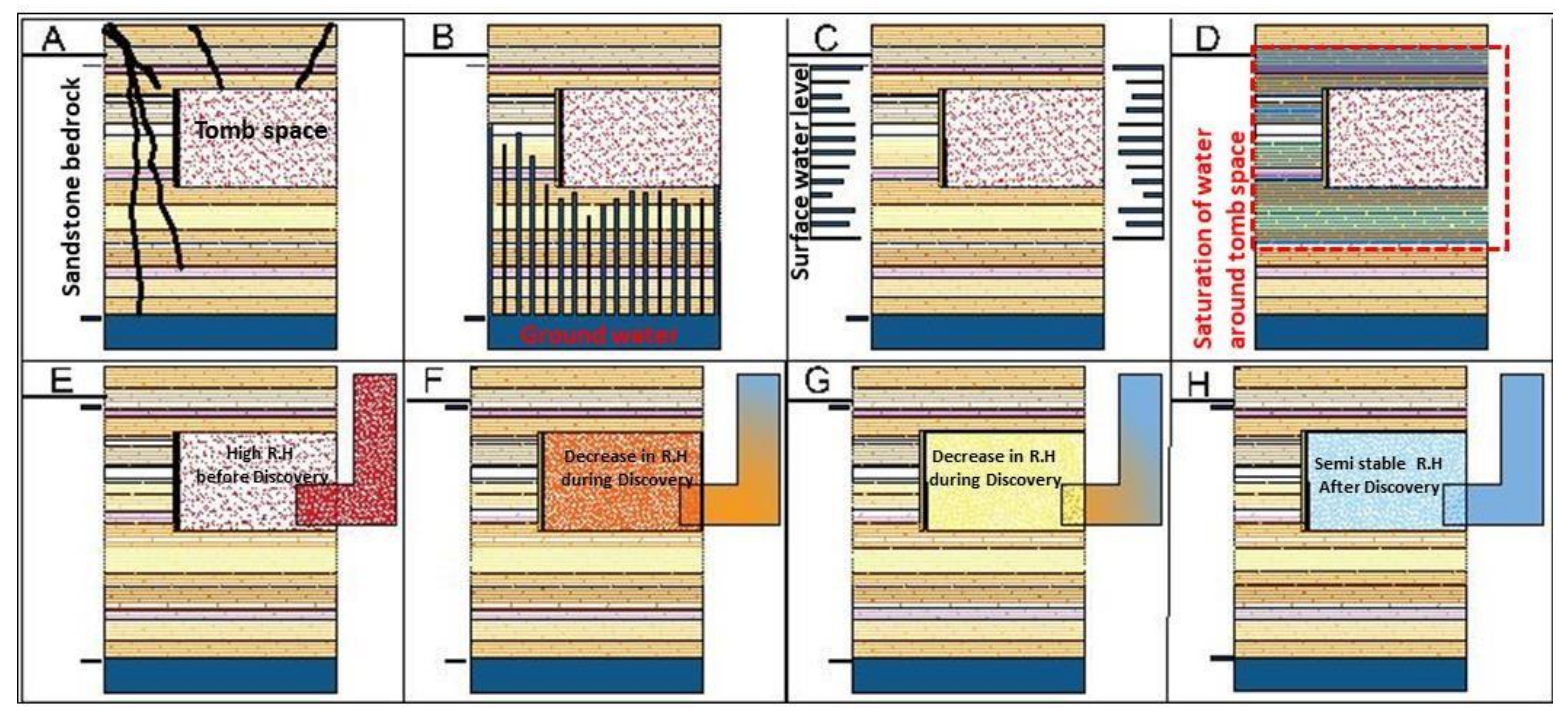

Fig.6. Illustration showing multi-sources of moisture content in the Bannentiu tomb. A) the sandstone bedrock which the tomb carved in, the bedrock contains many vertical cracks. B) groundwater transport by capillary action. C) surface water levels around the tomb due to surface water of agriculture wastewater and sewage. D) saturation of water inside sandstone pores around the tomb space. The second group shows the relative humidity behavior inside the tomb $\mathrm{E}$ ) high $\mathbf{R}$.H. before opening the tomb. F) low decreasing in R.H. in the first weeks during the tomb discovery. G) Continuous decrease in R.H. during months. H) the relative stability of the decreasing in R.H. and its relationship to the relative humidity outside the tomb.

Iron and manganese have a more complex chemical mechanism than salt weathering, where the transport and movement of soluble reduced iron and manganese are related to the $\mathrm{pH}$ of the water ${ }^{3}$. Reduced iron $\left(\mathrm{Fe}^{+2}\right)$ and manganese $\left(\mathrm{Mn}^{+2}\right)$ can be mobilized in alkaline water, filling Bannentiu sandstone pores over hundreds of years from various sources. Iron and manganese ions remained suspended in the water with an increase in their concentration over time through the dissolution of sandstone components with other elements where there is no water movement considering the constant closure of the tomb over thousands of years since the $26^{\text {th }}$ dynasty. The movement and transportation of iron and manganese-laden water started with the tomb's opening for the first time when the airflow cycle started (Fig.7). Oxidation of iron, manganese, and their associated trace elements depends on several factors, including ions concentration in moving water, oxygen from inner air, speed of airflow change, organic compounds from binding media in the paint layer, microbial reactions from funeral furniture stored inside the tomb and the color binding medium, and finally old light sources from warm tungsten bulbs which causes high rates of temperature. These factors cause the fast oxidization for chemical reactions in the complex of iron, manganese, clay, and trace elements. Which make the same rock varnish crusts on the upper surfaces of wall

\footnotetext{
${ }^{1}$ Groot\& van Hees\& Wijffels., Selection of Plasters and Renders for Salt Laden Masonry Substrates.”, 1748.

${ }^{2}$ Rosina\& Sansonetti\& Erba, Focus on Soluble Salts Transport Phenomena: The Study Cases of Leonardo Mural Paintings at Sala Delle Asse (Milan), 649.

${ }^{3}$ Jaafar et al., Transfer of Arsenic, Manganese and Iron from Water to Soil and Rice Plant, 103748; Vesper, Chapter 36 - Contamination of Cave Waters by Heavy Metals, 324.
} 
paintings and confirms the ${ }^{1}$ basic rule for any hypothesis for the formation of desert varnish as it must explain the varnish layers' growth rate, and it must also include the influencing factor from biological or abiotic and the binding material for the varnish.

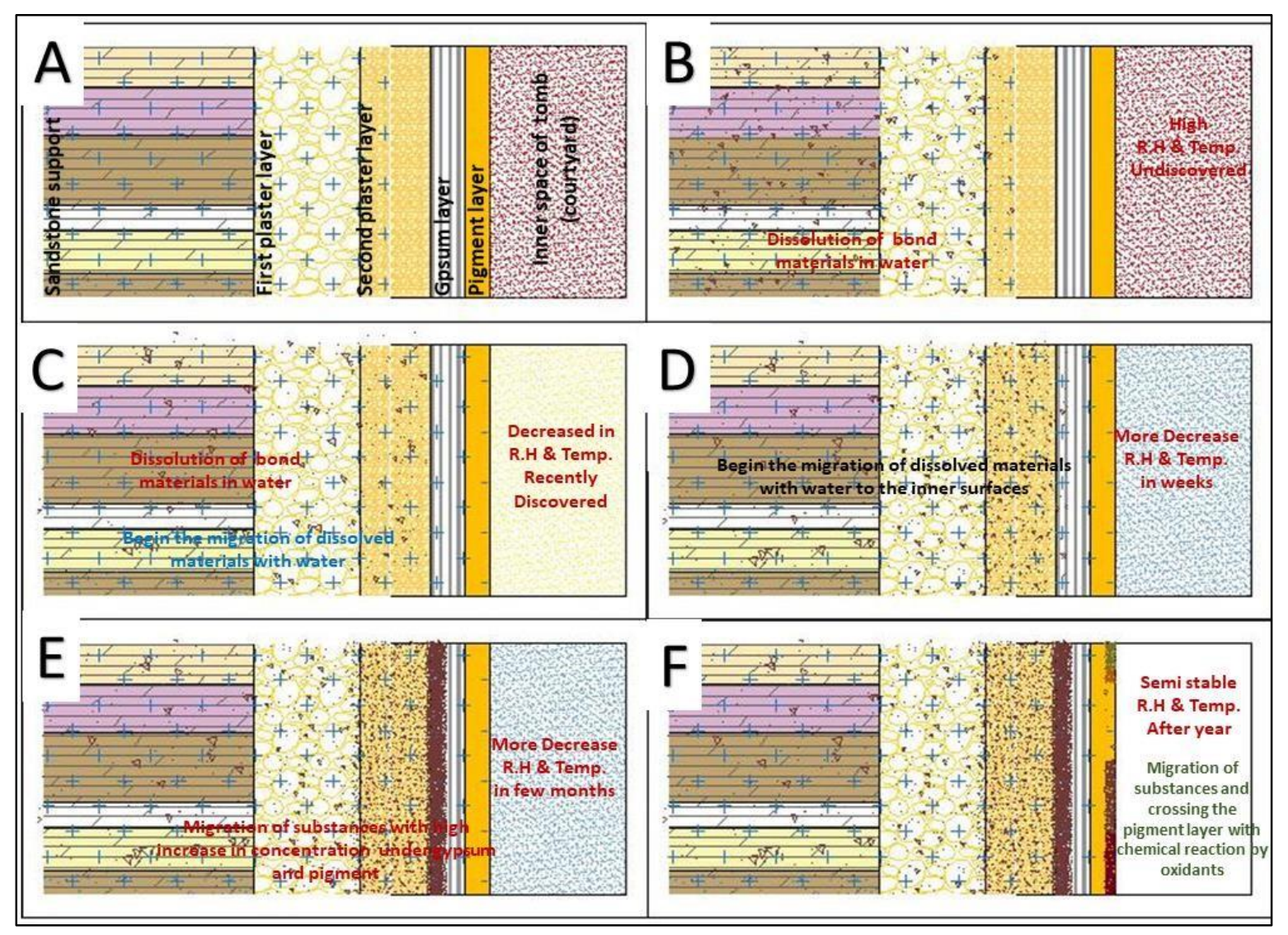

Fig.7. A) cross-sections contain the sandstone bedrock, plaster layers, paint layer, and part of tomb space. B, C, D) Showing the dissolution of ions in water and the movement and transportation with water in the change of R.H. finally, E, F) the oxidization of iron manganese clay and trace elements on the outer surface.

\section{CONCLUSION}

Wall painting is one of the most important cultural heritage properties and studying the deterioration phenomena is the best way to preserve it from damage and degradation. In this study, results indicated that black crusts are the same rock vanish and the chemical composition of the black crusts contains weakly crystallized compounds of iron oxides, manganese, and clay minerals, in addition to the presence of quartz as the main component. Also, many trace elements of heavy metals and RRE appear as minor components of different proportions and random arrangements within the black crusts; all these components appeared in a shiny black crust in a micrometer thickness. In most cases, the formation mechanism of rock varnish is not fully understood yet, but in the case of the Bannentiu tomb, high moisture content with an iron-rich sandstone bedrock causes the dissolution and movement of crust elements. After the movement of ion-leaden water to the upper surfaces, oxidization factors played an important role in black crusts formation as the microclimatic environment of the

\footnotetext{
${ }^{1}$ Dorn, Desert Rock Coatings, 164.
} 
tomb has multi-oxidization factors that helped in the rapid biotic, abiotic formation of the layers of rock varnish. 


\section{BIBLIOGRAPHY}

1. Afify, A.M\& Sanz-Montero, M.E\& Calvo, J.P., "Ironstone Deposits Hosted in Eocene Carbonates from Bahariya (Egypt) - New Perspective on Cherty Ironstone Occurrences", Sedimentary Geology, vol. 329, (2015), 81-97 (https://doi.org/10.1016/j.sedgeo.2015.09.010).

2. Afify, A.M\& Sanz-Montero, M.E\& Calvo, J.P\& Wanas, H.A., "Diagenetic Origin of Ironstone Crusts in the Lower Cenomanian Bahariya Formation, Bahariya Depression, Western Desert, Egypt", Journal of African Earth Sciences, vol. 101, (2015), 333-49 (https://doi.org/10.1016/j.jafrearsci.2014.10.005).

3. Ali, Mona., Restoration study of wall paintings in tombs dated to the late period (twenty-sixth dynasty) with application on a selected tomb, Ph.D. thesis, Cairo University, Faculty of Archaeology, conservation department, (1993).

4. Andreae, M. O\& Al-Amri, A\& Andreae, T. W\& Garfinkel, A\& Haug\& Jochum, K. P\& Stoll, B\& Weis, U., "Geochemical Studies on Rock Varnish and Petroglyphs in the Owens and Rose Valleys, California", PLOS ONE, vol. 15, no. 8, (2020). (https://doi.org/10.1371/journal.pone.0235421).

5. Baioumy, H. M., "Rare Earth Elements, $\mathrm{S}$ and Sr Isotopes and Origin of Barite from Bahariya Oasis, Egypt: Implication for the Origin of Host Iron Ores", Journal of African Earth Sciences, vol. 106, (2015), 99-107 (https://doi.org/10.1016/j.jafrearsci.2015.03.016).

6. Baioumy, H. M\& Khedr, M. Z\& Ahmed, A. H.), "Mineralogy, Geochemistry and Origin of Mn in the High-Mn Iron Ores, Bahariya Oasis, Egypt", in: Ore Geology Reviews, vol. 53, (2013), 63-76 (https://doi.org/10.1016/j.oregeorev.2012.12.009).

7. Catuneanu, O\& Khalifa, M. A\& Wanas, H. A., "Sequence Stratigraphy of the Lower Cenomanian Bahariya Formation, Bahariya Oasis, Western Desert, Egypt", in: Sedimentary Geology, vol. 190, no. 1 (2006), 121-37 (https://doi.org/10.1016/j.sedgeo.2006.05.010).

8. Chen, Hung-Lin\& Liu, Fu-Yu\& Xiao, X\& Jing, H\& Gao, B\& Zou, D\& Chen, Ch., "VisibleLight-Driven Photocatalysis of Carbon Dioxide and Organic Pollutants by $\mathrm{MFeO}_{2}(\mathrm{M}=\mathrm{Li}, \mathrm{Na}$, or K)", in:Journal of Colloid and Interface Science, vol. 601, (2021), 758-72 (https://doi.org/10.1016/j.jcis.2021.05.156).

9. Dietzel, M\& Kolmer, H\& Pölt, P\& Simic, S., "Desert Varnish and Petroglyphs on Sandstone Geochemical Composition and Climate Changes from Pleistocene to Holocene (Libya)", in: Geochemistry, vol. 68, no. 1 (2008), 31-43 (https://doi.org/10.1016/j.chemer.2007.03.001).

10. Dorn, R.I., "4.5 Rock Coatings", In: Treatise on Geomorphology, vol. 4, San Diego, CA 2013, 70-97 (https://doi.org/10.1016/B978-0-12-374739-6.00066-X).

11. Dorn, R.I., "Desert Rock Coatings", In: Geomorphology of Desert Environments, Dordrecht, Netherlands, (2009), 153-86 (https://doi.org/10.1007/978-1-4020-5719-9_7).

12. Dorn, R.I\& Krinsley, D., "Spatial, Temporal and Geographic Considerations of the Problem of Rock Varnish Diagenesis", Scale Issues in Geomorphology, vol. 130, no. 1 (2011), 91-99 (https://doi.org/10.1016/j.geomorph.2011.02.002).

13. Esposito,A\& Ahmed,E\& Ciccazzo,S\& Sikorski,J\& Overmann, J\& Holmström,S\& Brusetti, L., "Comparison of Rock Varnish Bacterial Communities with Surrounding Non-Varnished Rock Surfaces: Taxon-Specific Analysis and Morphological Description", in: Microbial Ecology, vol. 70, no. 3 (2015) 741-50 (https://doi.org/10.1007/s00248-015-0617-4).

14. Fakhry, A., "The Oases of Egypt, II. Bahriyah and Farafra Oases", in: Revised ed. Vol. 2. American University of Cairo press, Egypt, (2003), 128-163.

15. Frierdich, A. J\& Hasenmueller, E.A\& Catalano, J. G., "Composition and Structure of Nanocrystalline $\mathrm{Fe}$ and Mn Oxide Cave Deposits: Implications for Trace Element Mobility in Karst Systems", in: Chemical Geology, vol. 284, no. 1 (2011), 82-96 (https://doi.org/10.1016/j.chemgeo.2011.02.009).

16. Goldsmith, Y., Characterizing Rock Varnish Developed on Earliest Holocene Negev Flint Artifacts as a Potential Paleoenvironmental or Paleoclimatic Indicator, Master thesis, Hebrew University, (2011),18-89. 
17. Groot,C\& van Hees, R\& Wijffels, T., "Selection of Plasters and Renders for Salt Laden Masonry Substrates", in: Construction and Building Materials, vol. 23, no. 5 (2009), 1743-1750 (https://doi.org/10.1016/j.conbuildmat.2008.09.013).

18. Jaafar, M\& Shrivastava, A\& Bose, S\& Felipe-Sotelo, M\& Ward, N., "Transfer of Arsenic, Manganese and Iron from Water to Soil and Rice Plants: An Evaluation of Changes in Dietary Intake Caused by Washing and Cooking Rice with Groundwater from the Bengal Delta, India", in: Journal of Food Composition and Analysis, vol. 96, (2021), 103748. (https://doi.org/10.1016/j.jfca.2020.103748).

19. Kamh, G\& Shehata, A\& Oguchi, C\& Rabea, R\& El-Sayed, S., "Geological and Geotechnical Parameters Controlling Wall Paints Detachment at Selected XXVI Dynasty Tombs, Bahariya Oasis, Egypt", in: Restoration of Buildings and Monuments, vol. 19, no. 1 (2013) 11-30 (https://doi.org/10.1515/rbm-2013-6570).

20. Khalaf, M\& Catuneanu, O., "Sedimentology of the Fluvial and Fluvio-Marine Facies of the Bahariya Formation (Early Cenomanian), Bahariya Oasis, Western Desert, Egypt", in: Journal of African Earth Sciences vol. 51, no. 2 (2008), 89-103 (https://doi.org/10.1016/j.jafrearsci.2007.12.004).

21. Khalifa, E\& Abdel Wahed, M\& Maged, A\& Mokhtar, H., "Volcanic Geosites and Their Geoheritage Values Preserved in Monogenetic Neogene Volcanic Field, Bahariya Depression, Western Desert, Egypt: Implication for Climatic Change-Controlling Volcanic Eruption”, in: Geoheritage, vol. 11 (2019) 855- 873 (https://doi.org/10.1007/s12371-018-0336-6).

22. Krinsley, D\& Dorn, R\& DiGregorio, B.,"Astrobiological Implications of Rock Varnish in Tibet." Astrobiology, vol. 9, no. 6 (2009) 551-62 (https://doi.org/10.1089/ast.2008.0238).

23. Krumbein,W. E\& and Jens, K., "Biogenic Rock Varnishes of the Negev Desert (Israel) an Ecological Study of Iron and Manganese Transformation by Cyanobacteria and Fungi", in: Oecologia, vol. 50, no. 1 (1981), 25-38 (https://doi.org/10.1007/BF00378791).

24. Lozano (Rafael P.), and Rossi (Carlos), "Exceptional Preservation of Mn-Oxidizing Microbes in Cave Stromatolites (El Soplao, Spain)", Sedimentary Geology vol. 255-256, (2012) 42-55. (https://doi.org/10.1016/j.sedgeo.2012.02.003).

25. Macholdt, D.S\& Jochum, K.P\& Pöhlker, C\& Arangio, A\& Förster, J\& Stoll, B\& Weis, U., et al., "Characterization and Differentiation of Rock Varnish Types from Different Environments by Microanalytical Techniques", in: Chemical Geology, vol. 459 (May 25, 2017), 91-118 (https://doi.org/10.1016/j.chemgeo.2017.04.009).

26. Marszałek, M\& Alexandrowicz, Z \& Rzepa, G "Composition of Weathering Crusts on Sandstones from Natural Outcrops and Architectonic Elements in an Urban Environment", in: Environmental Science and Pollution Research vol. 21, (2014), 14023-14036 (https://doi.org/10.1007/s11356-014-3312-y).

27. Nowinski, P., Desert Varnish as an Indicator of Modern-Day Air Pollution in Southern Nevada, Ph.D. thesis, University of Nevada Las Vegas, (2009).

28. Perry, R\& Engel, M\& Botta, O\& Staley, J., "Amino Acid Analyses of Desert Varnish from the Sonoran and Mojave Deserts", in: Geomicrobiology Journal, vol. 20, no. 5 (2003, 427-38 (https://doi.org/10.1080/713851132).

29. Perry, R\& Kolb, V., "Biological and organic constituents of desert varnish: review and new hypotheses", in Hoover R. B. (ed.), Instruments, Methods, and Missions for Astrobiology VII, Proceedings of SPIE Vol. 5163, Held in San Diego, California, United States, 3-8 August 2003, Bellingham, WA,( SPIE publishing, 2004), 202-217 (https://doi.org/10.1117/12.509695).

30. Plyusnina, E\& Sallam, E\& Ruban, D.,"Geological Heritage of the Bahariya and Farafra Oases, the Central Western Desert, Egypt”, in: Journal of African Earth Sciences, vol. 116 (2016), 15159 (https://doi.org/10.1016/j.jafrearsci.2016.01.002).

31. Rosina, E\& Sansonetti, A\& Erba, S., "Focus on Soluble Salts Transport Phenomena: The Study Cases of Leonardo Mural Paintings at Sala Delle Asse (Milan)", in: Construction and Building Materials, vol. 136 (2017), 643-52 (https://doi.org/10.1016/j.conbuildmat.2016.08.014).

32. Sherbiny, H\& Bassir, H., "The Representation of the Hedgehog Goddess Abaset at Bahariya Oasis," in: Journal of the American Research Center in Egypt, vol. 50 (2014), 171-89 (https://doi.org/10.5913/jarce.50.2014.a023). 
33. Vesper, D. J., "Chapter 36 - Contamination of Cave Waters by Heavy Metals", In: Encyclopedia of Caves (Third Edition), William B. White, David C. Culver, and Tanja Pipan (Ed.), Academic Press, Amsterdam, (2019), 320-325 (https://doi.org/10.1016/B978-0-12-814124-3.00035-2).

34. Vicenzi, E. P\& Grissom, C.A\& Livingston, R\& Weldon-Yochim, Z., "Rock Varnish on Architectural Stone: Microscopy and Analysis of Nanoscale Manganese Oxide Deposits on the Smithsonian Castle, Washington, DC", in: Heritage Science, vol. 4 (2016), 26 (https://doi.org/10.1186/s40494-016-0093-2).

35. Wayne,D\& Diaz,T\& Fairhurst, R\& Orndorff , R\& Pete, D. V., "Direct Major- and TraceElement Analyses of Rock Varnish by High-Resolution Laser Ablation Inductively-Coupled Plasma Mass Spectrometry (LA-ICPMS)", in: Applied Geochemistry, vol. 21, no. 8 (2006) 14101431 (https://doi.org/10.1016/j.apgeochem.2006.04.005). 